\title{
Krzysztof Gryz (red.), Człowiek droga Kościoła. Moralne aspekty nauczania Jana Pawła II, Wydawnictwo Świętego Stanisława BM, Kraków 2004, 528 s.
}

Człowiek ujmowany w kategoriach bytu osobowego był zawsze jednym z głównych elementów naukowych oraz duszpasterskich wystąpień Ojca Świętego Jana Pawła II. W swoich rozważaniach naukowych uwzględniał poszukiwanie prawdy o człowieku obejmującej wymiar empiryczny, mistyczny i fenomenologiczny, gdyż Papież nie pomijał żadnych uwarunkowań człowieka i doceniał wszystkie jego potrzeby: fizyczne, moralne, intelektualne, czy religijne, a także podkreślał, że ze względu na swoje ciało człowiek stanowi część przyrody. Ojciec Święty uważał, iż właśnie błędne rozumienie człowieka stoi za wszystkimi działaniami, które traktując go instrumentalnie, zapominają o jego godności, gdyż właśnie człowiek jako osoba posiada tę wyjątkową wartość, iż powinien być afirmowany dla niego samego.

Uwzględniając 25-lecie pontyfikatu Ojca Świętego Jana Pawła II, który tak mocno i z takim oddaniem podkreślał, a nawet można powiedzieć, że walczył o godność każdego człowieka, a także dostrzegając zagrożenia oraz kryzys moralny współczesnego świata, a także różnego rodzaju inicjatywy próbujące redukować wielkość człowieka jako dziecka Bożego, wydaje się jak najbardziej właściwe zauważenie książki Człowiek droga Kościoła. Moralne aspekty nauczania Jana Pawła II, która powstała pod redakcją ks. Krzysztofa Gryza. Między innymi na wspomniane wyżej przyczyny powstania recenzowanej publikacji wskazał także w Przedmowie ks. dr hab. Jan Orzeszyna, prof. PAT: „Ojciec Święty w całym 25-letnim pontyfikacie mówi o godności człowieka, który jest drogą Kościoła, stworzonym przez Boga i odkupionym przez Chrystusa... Niniejsza publikacja stanowi owoc refleksji pracowników naukowych Katedry Teologii Moralnej Ogólnej i Katedry Teologii Moralnej Szczegółowej Wydziału Teologicznego Papieskiej Akademii Teologicznej w Krakowie. Stanowi ona zbiór artykułów, które powstawały w ciągu 25-lecia pontyfikatu Jana Pawła II, a które zostały poświęcone Jego nauczaniu. Większość zamieszczonych w książce artykułów była już wcześniej publikowana w różnych czasopismach teologicznych, tylko niektóre z nich są nowe. Publikacja jest darem dla Ojca Świętego Jana Pawła II z okazji 25-lecia Jego pontyfikatu. Stanowi ona wyraz szacunku i miłości krakowskich teologów moralistów wobec Namiestnika Chrystusowego i jest skromnym wyrazem ich wdzięczności za wielki dar pontyfikatu"'.

1 Człowiek droga Kościoła. Moralne aspekty nauczania Jana Pawła II, K. Gryz (red.), Kraków 2004, s. 5-6. 
Bardzo obszerna, bo licząca 528 stron, recenzowana książka, została wydana w Wydawnictwie Świętego Stanisława BM w Krakowie w ramach prac Instytutu Jana Pawła II w Krakowie. Brak recenzji naukowej zapewne należy tłumaczyć tym, iż przeważająca część artykułów była już publikowana w czasopismach naukowych. Omawiana praca składa się z Przedmowy opiekuna Specjalizacji Teologii Moralnej Wydziału Teologicznego PAT w Krakowie, ks. dr. hab. Jana Orzeszyny, prof. PAT, artykułu wprowadzającego w problematykę niniejszej publikacji, w którym zauważono, że nauczanie Papieża o moralności jest skupione na człowieku, na wezwaniu do poszanowaniu jego godności, jednak to nie człowiek stanowi centrum tego nauczania, lecz Chrystus (J. Orzeszyna, Przesłanie moralne Jana Pawła II) oraz trzydziestu dwóch tekstów pogrupowanych w siedmiu częściach.

W pierwszej części Moralne watki papieskich dokumentów zamieszczono pięć tekstów (J. Kowalski, Refleksje moralisty na marginesie "Redemptor hominis”; B. Mielec, Encyklika "Dives in misericordia” a teologia moralna fundamentalna; J. Kowalski, Zadania teologów moralistów w świetle encykliki „Veritatis splendor”; J. Kowalski, Kontekst powstania encykliki „Evangelium vitae” i jej istotne treści; J. Kowalski, Problematyka moralna w encyklice "Fides et ratio"). Analizując konteksty powstania i treść dokumentów papieskich (Redemptor hominis, Dives in misericordia, Veritatis splendor, Evangelium vitae i Fides et ratio) m.in. podkreślono, że Jan Paweł II nie próbował dać jakiegoś syntetycznego resumé etyki chrześcijańskiej, czy też jakiegoś określenia w punktach tego, czym ona powinna być. $\mathrm{Z}$ drugiej jednak strony Papież zwracał uwagę niektórym moralistom na popełniane błędy, które rodziły relatywizm moralny powodujący zaprzepaszczenie dziedzictwa moralnego wypracowanego przez wieki. Apelował o mądre poszukiwanie sensu ostatecznego i globalnej egzystencji, czyli odnoszenie się do metafizyki.

W części drugiej Człowiek znajdują się dwa teksty (K. Gryz, Konferencje akademickie Karola Wojtyly o istocie człowieka; J. Kowalski, Antropologia filozoficzna i teologiczna Karola Wojtyly w jego nauczaniu papieskim), z których dowiadujemy się, że Jan Paweł II był kontynuatorem myśli antropologiczno-personalistycznej oraz że fundamentem jego antropologii jest doświadczenie czynu ludzkiego. Natomiast teologia ciała stanowi ciekawy fragment teologicznej antropologii Jana Pawła II i stanowi jego nowatorski wkład do filozofii człowieka i etyki chrześcijańskiej.

W następnej, trzeciej, części Małżeństwo i rodzina umieszczono siedem artykułów (A. Świerczek, Jana Pawła II nauka o oblubieńczym znaczeniu ciała ludzkiego; W. Gubała, Rodzina w stużbie życia i miłości. Od „Humanae vitae” do „Evangelium vitae”; W. Gubała, Kobieta w nauczaniu Jana Pawła II; A. Świerczek, Malżeństwo i rodzina wobec zagrożenia życia; A. Świerczek, Wiara a moralność w życiu rodziny. Refleksja na kanwie encykliki „Veritatis splendor”; K. Gryz, Ksztat- 
towanie człowieczeństwa przez miłość. Idea wychowania w nauczaniu Jana Pawła II; W. Gubała, Ludzie starsi w nauczaniu Jana Pawła II). Jan Paweł II wskazywał, iż pojęcie "komunia” odnosi się do relacji międzyosobowej między „ja” i „ty”, natomiast pojęcie „wspólnota” przekracza ten układ w stronę „społeczności”, w kierunku „my”. I właśnie „komunia osób” daje początek wspólnocie, jaką jest rodzina będąca wspólnotą życia i miłości - pierwszą i najważniejszą drogą człowieka. Istotny jest związek rodzicielstwa $\mathrm{z}$ wychowaniem, gdyż rodzenie nie jest tylko faktem fizjologicznym, lecz posiada także wymiar duchowy. Każdego człowieka, również starego, należy widzieć jako kogoś, kto wnosi cenny wkład w życie rodzinne i społeczne. Między moralnością a religijnością istnieje organiczna jedność, bowiem wiarę człowieka rozpoznaje się nie tylko po praktykach religijnych, ale nade wszystko po jego życiu moralnym. Może trochę szkoda, iż nie zamieszczono $\mathrm{w}$ tej części tekstu odnoszącego się do młodzieży, a przecież młodym Papież poświęcił jakże wiele miejsca w swoim nauczaniu.

Z kolei w czwartej części $W$ obronie życia znajdziemy siedem opracowań (J. Orzeszyna, Aktualne zagrożenia życia ludzkiego w świetle encykliki Jana Pawła II „Evangelium vitae”; W. Gubała, Jan Paweł II o etyce lekarskiej; J. Kowalski, "Evangelium vitae" i etyka katolicka o zapłodnieniu pozaustrojowym; T. Kraj, Problemy wspótczesnej genetyki w nauczaniu Jana Pawła II; K. Banko, Postulat obrony życia u Jana Pawła II a moralna ocena zapłodnienia pozaustrojowego; K. Gryz, Teologiczno-moralne aspekty eutanazji; J. Kalniuk, Wizja cierpienia $w$ nauczaniu Jana Pawła II). Niestety mimo tzw. pozornej promocji życia mamy do czynienia z „kulturą śmierci”, swojego rodzaju „wojną silnych i bezsilnych”, to jednak sumienie nieustannie przypomina o świętości oraz nienaruszalności życia. Jan Paweł II odnosił się również do problemów etyki lekarskiej i humanizacji medycyny w stosunku do osoby. $Z$ jednej strony postęp techniczny pomaga człowiekowi, jednak $\mathrm{z}$ drugiej naraża na niebezpieczeństwo przeżycie i integralność osoby ludzkiej. Ważne jest również, by człowiek potrafił odkryć sens cierpienia, a także iść z pomocą cierpiącym.

W piątej części Zagadnienia społeczne zostało przedstawionych osiem tekstów (J. Kowalski, Kultura w integralnym rozwoju człowieka w świetle nauczania papieża Jana Pawła II; K. Banko, Wartości moralne kultury w świetle encykliki Jana Pawła II „Fides et ratio”; J. Kowalski, Personalistyczny wymiar pracy w świecie nauczania papieża Jana Pawła II; K. Gryz, Ojczyzna jest moja matka. Słowo o patriotyzmie Jana Pawła II; J. Kowalski, Węzłowe problemy życia społecznego w nauczaniu Jana Pawła II podczas IV wizyty w kraju; J. Kowalski, Papieskie inspiracje jasnogórskiej formacji postaw patriotyczno-religijnych $w$ ostatnich latach panowania totalitaryzmu; J. Kowalski, Jan Paweł II o chrześcijaństwie jako nowej wiośnie Europy; M. Leśniak, Troska Jana Pawła II o nowy kształt Europy). Dokonane przez Jezusa Chrystusa odkupienie potwierdza niezbywalną godność i wartość osoby ludzkiej. Jan Paweł II poszerzał i pogłębiał chrześcijańską dok- 
trynę kultury poprzez dialektykę poszukującą prawdy o człowieku we wszystkich jego wymiarach, bowiem kultura jest wyrazem człowieka, potwierdzeniem człowieczeństwa. Ojciec Święty równocześnie podkreślał, że praca ma istotny związek z człowiekiem, gdyż jest ona powołaniem człowieka, jest współdziałaniem ze Stwórcą i uczestnictwem w krzyżu Chrystusa. Papież wskazywał także na zobowiązania wobec małżeństwa i rodziny, ale i wobec Ojczyzny i Europy.

Szósta część Kapłan zawiera jedynie dwa teksty (J. Orzeszyna, Posłannictwo i obowiązki spowiednika w nauczaniu Jana Pawła II; J. Kowalski, Współczesne wyzwania do powrotu do wspólnotowego życia księży diecezjalnych), w których ukazano sakralność posługi spowiednika, który winien być dyskretny oraz posiadać wiedzę z teologii moralnej i prawa kanonicznego. Jan Paweł II podając propozycje zachęcał również do przezwyciężania samotności w wymiarze osobistym, ale i duszpasterskim.

Natomiast w ostatniej, siódmej, części Człowiek wobec papieskiego słowa zamieszczono tylko jeden artykuł (K. Gryz, Stuchany, kochany, krytykowany...? Uwagi na temat recepcji papieskiego nauczania), w którym przypomniano, że nauczanie papieskie wielokrotnie było przyjmowane krytycznie i poddawane różnego rodzaju weryfikacji.

Należy zauważyć, iż dobrze się stało, iż powstała niniejsza publikacja, która w sposób kompetentny, rzetelny, jasny, ale i przekrojowy przybliża aspekty nauczania moralnego Jana Pawła II, który wskazywał na wielopłaszczyznowy kryzys, który współcześnie dotyka człowieka, a jego symptomami są różnego rodzaju zagrożenia odrzucające racje istnienia i godności człowieka jako osoby ludzkiej: kryzys wiary, relatywizm i subiektywizm moralny, fascynacja wartościami zmysłowymi i deprecjacja wartości duchowych, odczucie absurdalności życia i świata. Jak to zostało podkreślone w Przedmowie ks. dr. hab. Jana Orzeszyny, prof. PAT: „Ufam, że książka pt. Człowiek droga Kościoła. Moralne aspekty nauczania Jana Pawła II pozwoli wszystkim, którzy po nią sięgną, zgłębić znajomość bogatego nauczania papieża Jana Pawła II. Gratuluję Redaktorowi cennego opracowania, a Czytelnikom życzę, by stanowiła dla nich inspirację do nieustannego poznawania papieskiego nauczania"2 $\mathrm{Z}$ całą pewnością recenzowana publikacja może stać się impulsem, zachętą, a nawet wprowadzeniem do dalszego poszukiwania i zgłębiania papieskiego nauczania, a także może przyczynić się do mobilizacji czytelników do realizacji duchowego testamentu Ojca Świętego Jana Pawła II.

ks. Józef Stala Uniwersytet Jana Pawła II w Krakowie 